\title{
Poética da sacada: do corpo ao caco contemporâneo
}

Pedro Marques

Universidade Federal de São Paulo

rrisco dividir em três grandes linhagens a poesia
contemporânea brasileira. Minimizando critérios
lineares de seleção ("exemplo de época") e síntese ("símbolo de geração"), aproximo textos a partir de práticas poéticas comuns. A primeira, poética do clássico, inventa a partir de convenções e procedimentos normativos, emulando autores de uma tradição que venta da antiguidade. A segunda, poética do projeto, gera poemas e livros dentro de planos e comunidades algo coesas. A terceira, poética da sacada, faz do poema a performance do instante, o lampejo da ideia, o caco poético em coletâneas às vezes até coletivas. Há poetas, óbvio, que transitam ou atuam em mais de uma linhagem. De todo modo, cada nota dessa tríade de procedimentos desvela diálogos internos, constantes técnicas e referências próprias.

$\mathrm{Na}$ acepção corrente, sacada é tirar bruscamente alguma coisa do seu lugar. Aplicada à linguagem, tal deslocamento, daquilo que era estável,revive a tradição que entende a poesia como palco propício à renovação linguística. A sacada ecoa, assim, a teoria da metáfora sedimentada por Aristóteles na Poética e no Livro III da Retórica.

${ }^{1}$ Para Caio Gagliardi, Francine Ricieri, Marcelo Moreschi, Marcelo Veronese, Marco Catalão e Pablo Simpson. 
A metáfora consiste no transportar (epiphora) para uma coisa o nome (onomatos) de outra (allotriou), ou de gênero para a espécie (apo tou genous epi eidos), ou da espécie para o gênero (apo tou eidous epi genos), ou da espécie de uma para a espécie de outra (apo tou eidous epi eidos), ou por analogia (è kata to analagon) $(1457 \mathrm{~b} 6)^{2}$

Para Paul Ricoeur, há quatro traços relevantes nessa definição, início de uma história poético-retórica que orientou o conceito de metáfora à palavra. "A teoria dos tropos - ou figuras de palavras - está contida in nuce na definição de Aristóteles". ${ }^{3}$ A palavra surge como unidade primal do discurso (lógos), articulador dos diversos níveis da linguagem: palavra, frase, estrofe, texto, estilo, etc. Essa célula de sentido desloca-se o tempo todo, pois a própria dinâmica da pronunciação/elocução exige lances metafóricos. Assim, o heroico verso de Luís de Camões "O mundo todo abarco e nada aperto" ${ }^{4}$ dispõe: 1) ação impossível de envolver nos braços (abarcar e abraçar compartilham étimo) o globo; 2) ação crível de circunavegar (o termo barco se insinua) o globo, sem nisso achar vantagem; 3) sobreposição das imagens análogas a partir da mesma palavra (abarco), eis o efeito poético.

Para Ricoeur, "a metáfora é definida em termos de movimento: a epiphorá de uma palavra é descrita como uma sorte de deslocamento de... para...". Essa mudança carrega informação e perplexidade, ativa interesse pelo movimento em si de transposição, pelo processo que leva palavras de classes idênticas ou não a trocar sentidos. Para explicar o conceito, Aristóteles lança mão de uma metáfora tomada à ordem do movimento: phora, utilizada na Física, significa a mudança

\footnotetext{
${ }^{2}$ ARISTÓTELES, 1973, p. 462. ARISTÓTELES, 1974, p. 204.

${ }^{3}$ RICOEUR, 2000, p. 29

${ }^{4}$ CAMÕES, 1977, p. 55.

${ }^{5}$ RICOEUR, 2000, p. 30.
} 
de lugar de um corpo. O engenho matemático de tecer e identificar trânsitos semânticos e concretos (correspondências e proporções; desproporções e dissonâncias etc.) chegou a definir o homem discreto, poeta ou ouvinte-leitor, a partir do século XVI. Qualidade e raridade de deslocamento baseiam, de fato, a teoria da agudeza de Baltazar Gracián (Agudeza y Arte de Ingenio, de 1648), a preferência pela expressão peregrina à expressão comum. Manoel Botelho de Oliveira, na silva "À Ilha de Maré", simetriza quatro campos: geográfico (ilha e mar), anatômico (corpo masculino e feminino), amoroso (sintomas do afeto) e mitológico (Netuno).“Jaz em oblíqua forma e prolongada / A terra de Maré, toda cercada / De Netuno, que, tendo o amor constante, / Lhe dá muitos abraços por amante, / E, botandolhe os braços dentro dela, / A pretende gozar, por ser mui bela." ${ }^{\prime 6}$

Para Ricoeur, metáfora é "transposição de um nome que Aristóteles denomina estranho (allotrios), isto é, 'que... designa outra coisa' (1457b 7), 'que pertence a outra coisa' (1457b 31)". . Metáfora como desvio do ordinário, do vulgar (kúpıov), isto é, daquilo que é usual ou próprio a nós. Aristóteles destaca, ainda, que o uso pode ser corrente e estrangeiro ao mesmo tempo, pois o regular para este interlocutor vira anormalidade para aquele (1457b 3-5). No final do XVIII, noções como decoro, imitação e engenho perdem força, respectivamente, para individualismo, originalidade e inspiração. Este trio rearranja a mímesis e metáfora aristotélicas, dando ao poeta poderes para intervir no curso da língua, amparado no nacionalismo da hora, e para criar realidades naturais ou doentias. Em "Antropofagia", Carvalho Júnior transpõe o campo semântico do canibalismo - usado no período colonial para justificar conversão, escravidão e matança de índios - à seara do sexo, num humor animalesco que dialoga com o indianismo vigente: "Mulher! Ao ver-te nua, as formas opulentas

\footnotetext{
${ }^{6}$ OLIVEIRA, 2005, p. 127.

${ }^{7}$ RICOEUR, 2000, p. 32.
} 
/Indecisas luzindo à noite, sobre o leito, / Como um bando voraz de lúbricas jumentas, / Instintos canibais refervem-me no peito." ${ }^{8}$

Para Ricoeur,a metáfora é o motor que cria sentidos na linguagem. "A metáfora surge em uma ordem já constituída por gêneros e por espécies, e por um jogo já regrado de relações: subordinação, coordenação, proporcionalidade ou igualdade de relações". ${ }^{9}$ Há transporte porque há ordem convencionada. Metáfora é violação do estável: "dar ao gênero o nome da espécie, ao quarto termo da relação proporcional o nome do segundo, e reciprocamente, é simultaneamente reconhecer e transgredir a estrutura lógica da linguagem (1457b 6-20)". ${ }^{10}$ Se o gênio romântico emplaca a percepção torta, o vanguardista danifica a normatividade da língua. Se distúrbios de seleção e combinação, ocasionados por afasia, minam o funcionamento da linguagem, como descreve Jakobson, ${ }^{11}$ a intensificação de processos metafóricos e metonímicos por certa vanguarda colapsa a própria norma estabelecida. No "Poema da Amiga I", de Mario de Andrade: "e só vi no perfil da cidade / O arcanjo forte do arranha-céu cor-de-rosa / Mexendo asas azuis dentro da tarde" ${ }^{12}$ Os pares arcanjo/arranha-céu e asas azuis/tarde juntamse no eixo da similaridade, numa sintaxe esquisita, embora sem agramatismos e telegrafismos típicos do afásico com distúrbio de contiguidade, combinação e contexto. Já "Amor", ${ }^{13}$ de Oswald de Andrade, vale uma fala afásica com falha de similaridade, suprimindo conjunções, pronomes, artigos e preposições. Ao modo futurista, a condensação amor/humor é metáfora que define um ao outro sem contexto.

\footnotetext{
8 JÚNIOR, 1879.

9 RICOEUR, 2000, p. 38.

${ }^{10}$ RICOEUR, 2000, p. 38.

${ }^{11}$ JAKOBSON, 1992, p. 34-62.

${ }^{12}$ ANDRADE, 1983, p. 214.

${ }^{13}$ ANDRADE, 1981, p. 153.
} 
Cada tropo ou figura, produto do processo metafórico matricial, faz parte de um corpo textual (soneto, silva, décima, épica, coleção, etc.). Mesmo a pílula de Oswald compõe um livro/projeto maior. Propostas de vanguarda operam, não raro, como metáforas capitais a partir das quais se produz e lê tudo, espécie de extravio orientado. O projeto concretista exemplifica isso, suas formulações operam como algoritmo poético-interpretativo. Parte substancial da poesia brasileira dos últimos anos desaparece justamente com corpo ou projeto poéticos. Sacadas como metáforas sem todo linguístico ou intelectual, pilhas de pernas e braços sem poemas em corpo. Edifício retórico-poético arruinado. Sacada como unidade antepoema, ante-livro, provocando alguma alteração. Mas milhões de alfinetes cortam como uma só espada? O legado das sacadas, a produção mais popular de hoje, talvez seja funcionar como usina de reciclagem tropológica. Poetas conseguem selecionar, reaproveitar,refundir simulacros de corpos ainda que perecíveis e heterogêneos. A beleza do escombro, do retalho, do caco.

A sacada, em volume, supera surtos de versilibrismo ou concretismo. Leio muita gente saída a poeta: a maioria chega com sacadas, quase ninguém com madrigais, polirritmia, vídeo-poesia ou plano próprio. Remar o oceano de sacadas procedimento do dia, maneira como as pessoas têm vivido o poético - é necessário e inglório. É positivo constatar que seguimos respirando poesia. É crítico distinguir o que se faz por necessidade, passatempo, truque ou técnica, pois é do mercado editorial e da leitura heterônoma a confusão, bastando o sujeito fazer cara de poeta. A sacada, portanto, periga ser a suspensão da arte poética, o modo apreendido por osmose. Nada de novo, até o temido soneto passou por isso, e foi preciso discriminar um Raimundo Correia da massa de médicos, donas de casa, advogados e estudantes que sonetavam. 
Será o avesso da anedota de Mallarmé, isto é, para poetar hoje bastam ideias e palavras que se conformem? Será a tradução do tal caos contemporâneo (como se todo presente não fosse caótico a quem o viva), cabendo ao crítico o fenômeno e ao poeta a produção? Cuido da matéria em livros dos independentes aos empresariais, dos artesanais aos industrializados. Sacadas crescem no oficial e no paralelo. Editoras não garantem inusitado e qualidade. É preciso olhar por cima do muro de cadernos culturais, feiras e prêmios literários, marketing livreiro, locais de institucionalização como universidades e centros culturais. Mesmo grupos alternativos, muitos em cartaz na web, às vezes fecham-se em condomínios de cânones, gurus, craques, crenças e valores, miniaturas da academia e mercado que tanto questionam. A crítica ressalta o gigantismo da produção atual, das periferias aos centros, no entanto, em análises e valorações, segue ainda presa à divulgação de editoras e da velha imprensa (TV, jornal e revistas). É preciso garimpar iniciativas livres e inventivas. Agrupo aqui famosos e anônimos. Apenas nove modalidades de sacadas, sabendo que o mesmo texto pode desenvolver mais de uma. Não avalio autores, obras ou livros, apenas o procedimento. Os poemas ensejam simplesmente a poética da sacada.

II

1. Sacada som. Um dado acústico encanta, restituindo o frescor de adquirir uma língua. Aliterações e assonâncias viram objetivo em si, embora possam manter a função retórica. Em "o tempo certo," o "i" pula de tônica em tônica, insiste em irromper como dente novo. As dentais " $\mathrm{t}$ " $\mathrm{e}$ " $\mathrm{d}$ " intercalam-se, de fato, como fileira dentária.Uma harmonia imitativa que em Manoel de Barros perfaz a conexão entre sons linguísticos e sentidos naturais. Uma rede de correspondências idealizando o pacto ecológico homem/ 
meio ambiente. A repetição do sufixo "oso/osa", pejorativo em português brasileiro, é irônica, sentenciosa e valorativa. $\mathrm{O}$ ser lunático ("astroso"), ensimesmado ("insetoso") e sonoro ("violosa") é o poeta romântico, cujo dom místico o afasta da vida e comunicação ordinárias, ou seja, da prosa. No poema seguinte, a vibração de erres, que amplifica o trinado da cigarra, cessa de repente, restando o silêncio eloquente do pós ruído. Mas em vez de calar, a voz poética amplifica a subjetivação, feita cigarra de si. Pudera, cantor e cigarra são irmãos desde a velha Grécia.

\section{o tempo certo}

finalmente o siso

menino morto

tardio dente torto

(Antonio Geraldo Figueiredo Ferreira, Peixe e mingua, 2003)

Ditados (dois) inscritos na parede de uma tapera:

1. Homem astroso, sujeito insetoso e mulher violosa não acertam na prosa.

2. Para ser escravo da natureza o homem precisa de ser independente.

(Manoel de Barros, Concerto a céu aberto para solos de ave, 1991)

A serra elétrica das cigarras parou.

Tão de repente que o dia, que ela partia em dois, num estalo deitou ao chão suas metades.

Ficou só esta poça de silêncio, indiferente, 
e um tremor de alfinetes ardendo dentro da caixa

de onde se abre o quem.

(Claudia Roquette-Pinto, Corola, 2000)

2. Sacada palavra. Um ou mais termos são núcleo tensivo, e a armação textual funciona como preparação, forragem ou cenário. Uma chave de ouro espalhada, porque deixa de ser fim para ser centro do sentido. Neologismo, conceito, trocadilho, vocábulo estranho ou corrente enfeitiçam poeta e leitor feitos criança que aprendeu a falar, por exemplo, a palavra "oxigênio". Palavra imantada vira fetiche, embora em alguns casos o orbital semântico seja difuso e banal, talvez um dos efeitos daquela mediania que Célia Pedrosa ${ }^{14}$ vê na abertura da poesia à uniformização mercadológica. Em "Amar-amaro", já o título liga o gesto de tomar café ao topos, desde Safo, do amor em oxímoros como doce-amargo, quente-frio etc. Em "Visita”, ainda o eu lírico solitário e rotineiro, sedento de ter ou ser visita. A xícara, desta vez, metamorfoseia-se em música e coreografia, como se os próprios sons de "xícara" se metamorfoseassem nos de "caixinha". Um faz cantar em tom menor o significante ("dociamargo amaramaro"), outro canta em tom maior o significado. No fundo das cenas, o cotidiano crepuscular de Ribeiro Couto e Mario Pederneiras. Em "Poeira de aldeia 2", a voz de dentro de casa arrasta os olhos à casa alheia, onde a imaginação fermenta um correlato do poeta: artesão de bonecas. Em torno da palavra nuclear ("boneca") circunda a invenção do poema. A visão, depois de rasantes, ajusta o foco: poesia e boneca, depois de tanta arte, nascem nuas, frágeis, todavia míticas.

${ }^{14}$ PEDROSA, 2008, p. 41-42. 


\section{Amar-amaro}

Me desfaço de qualquer conclusão ou expectativa -

A manhã avança desfazendo-se da insônia e de todos ruídos (seriam estrelas, síntese em campo áspero?)

A ansiedade não me convém deixo todas notas pendentes (no fundo da xícara raspo o melado café dociamargo amaramaro insolúvel)

(Heitor Ferraz Mello, A mesma noite, 1997)

\section{Visita}

Diga que sou bem-vinda e me ofereça um café Quando a colher girar na xícara Ela se transformará numa caixinha de música E a colher numa bailarina.

(Ana Neustein, Poemas, 2012)

\section{Poeira de aldeia 2}

Sobre o chão das ruas não circulam bicicletas nem o girar de rodas mecânicas ameaça a manhã oblíqua.

Os pressentimentos crescem rente aos ossos 
os medos ganham o correr dos muros junto aos amigos.

Eu imagino (por livre imaginar) que numa das casas próximas banhada em sol mora um fabricante de bonecas.

Concebo o homem e suas criaturas a desfiarem intimidades no fim da tarde.

Bonecas tocadas em nudez de porcelana.

(Fernando Paixão, Poeira, 2001)

3. Sacada refrão. Uma frase matricial é mola e compasso do texto. Não precisa repetir inteira, apenas sua sintaxe vira fórmula anafórica. A musicalidade lírica reduz-se ao ritmo enumerativo, de memorização à la slogan. Muitas coletâneas, de fato, fazem dos títulos bordões publicitários. No poeta arguto, ao contrário da propaganda, o sentido do refrão desloca-se a cada nova martelada.Em "a mulher quer", arrolam-se desejos que se supõem antes automáticos que conscientes, como search list na web, daí o poema contar no conjunto "3 poemas com o auxílio do Google". A lista sugere que, com tantos clichês a vestir, a mulher deve querer mesmo é se matar. A ironia sobre os opcionais para mulher - alguns servem para homem - é tão judicativa quanto os padrões que expõe. O ritmo irritante leva ao suicídio sem variação ou questionamento. A complexidade escapa: por quê mulheres no século XXI desejam casar e ter filho? Em "Tempus fugit", a multiplicação da estrutura "o face é" ou "o face faz", de um lado, frisa a multidão de cliques anódinos e rentáveis à maior rede social do planeta; de outro, desmantela o próprio sentido 
do neologismo "Facebook", isto é, ali toda face é feliz e sem identidade. Se você tem tempo a perder, ótimo, do contrário melhor viver. A desgraça é que a vida real "não chega aos pés do Face". Já "Bebo"cria um ditirambo indie rock, com a adolescência que isso implica. O bordão "eu bebo", além da virada de copos e garrafas, apregoa o desejo de experimentar tudo que há de química, sensação, humanidade, saúde, doença. Quem se embebeda não se perde, acha a si mesmo sem Google ou Facebook. O poeta não defende posição, recoloca a velha lírica simposial num inusitado patamar de sarjeta.

\section{a mulher quer}

a mulher quer ser amada

a mulher quer um cara rico

a mulher quer conquistar um homem

a mulher quer um homem

a mulher quer sexo

a mulher quer tanto sexo quanto o homem

a mulher quer que a preparação

para o sexo aconteça

lentamente

a mulher quer ser possuída

a mulher quer um macho que a lidere

a mulher quer casar

a mulher quer que o marido seja seu companheiro

a mulher quer um cavalheiro que cuide dela

a mulher quer amar os filhos, o homem e o lar

a mulher quer conversar pra discutir a relação

a mulher quer conversa e o botafogo

quer ganhar

do flamengo 
a mulher quer apenas que você escute

a mulher quer algo mais do que isso, quer amor, carinho a mulher quer segurança

a mulher quer mexer no seu e-mail

a mulher quer ter estabilidade

a mulher quer nextel

a mulher quer ter um cartão de crédito

a mulher quer tudo

a mulher quer ser valorizada e respeitada

a mulher quer se separar

a mulher quer ganhar, decidir e consumir mais

a mulher quer se suicidar

(Angélica Freitas, Um útero é do tamanho de um punho, 2012)

\section{Tempus fugit}

O Face me dispõe na tela

O Face é uma flor-estrela

de boca aberta

O Face não é flor que se cheire

O Face jamais fica às moscas

O Face desmascara a farsa

do ready-made

A chuva é molhada

A pedra é dura

O céu, no Face, é azul

No Face, vai chegar a nossa vez

Hoje envio os parabéns

ao poeta Ron Silliman, 66

O Face é fake como

uma nêspera

O Face é tão fake como

o funeral de Neruda

O Face encara a verdade

de costas

O Face pega no nervo

excita na vigília 
desova presunto

O Face é um espião barato, prêt-à-porter, feito

para mim e para você

O Face

é muito mais que um videoteipe

é o arquivo do presente

é um avião não tripulado

uma abelha macho despejando mísseis

O Face

trafica pétalas

No Face, só há amigos

A vida

não chega aos pés do Face

(Régis Bonvicino, Estado crítico, 2013)

\section{Bebo}

Eu bebo o fundo

Eu bebo o oco

Eu bebo a vida em saúde do morto

Eu bebo sede

meu gole é um soco

Eu bebo toda a vantagem do louco

Eu bebo tudo

e bebo outros

Eu bebo com duas asas no bolso

Eu bebo mais leve

Eu bebo o escuro

Eu bebo a lua que sobe e desce

Eu bebo em tubos

Eu bebo a peste

Eu bebo rápido quanto mais mudo 
Eu bebo vermelho

Eu bebo sujo

e trombo com vultos que são eu mesmo

(Beso, Juventude supersônica, 2008)

4. Sacada chiste. Herdeira da blague modernista, reestilizada por alternativas dos anos de 1970, faz sucesso entre autores e público. Difícil de executar, pois facilmente suprime a arte poética. É que leitor ridente tolera enunciados que querem o riso de tirinhas, sem o desenho destas e o complexo sarcasmo epigramático. Algumas farpas, inclusive, ficam bem lidas na chave da prosa-piada de Marquês de Itararé, Stanislaw Ponte Preta ou José Simão. É terra de trocadilho, infâmia, deslocamento irônico, sacanagem, linguagem malandra. $\mathrm{O}$ dístico "Ganso" deriva da expressão idiomática sexual, "afogar o ganso, "soluções para os déficits nacionais. O cruzamento de registros diverte, conecta moralismo a atraso comportamental, prazeres do corpo reprimido a subdesenvolvimento políticoeconômico. "Saravá onan" toma de assalto "Un coup de dés" de Mallarmé, totem concretista, para definir a masturbação como aleijão sexual, quiçá farpeando um modo racionalonanista de poetar. "Delicadeza", eufemismo da grosseria à vista, enfeixa o trovão (fato sonoro-visual) que, no registro menos óbvio, é a flatulência (fato sonoro-olfativo) arrebentando a cena brega e doce da superfície: contemplar a amada depois da transa, mas assustar com gases que fedem e faíscam.

\section{Ganso}

só afogando o (passo de) ganso

vamos tirar o (Brasil do) atraso

(Ricardo Chacal, Letra elétrika, 1994) 


\section{saravá onan!}

um lance de dedos jamais abolirá o desejo

(Caio Carmacho, Livre-me, 2013)

\section{Delicadeza}

novamente a vi dormir

novamente o cheiro

e aquele último trovão

acendeu todo o quarto

iluminou sua nuca

(Fabiano Calixto, Sanguínea, 2007)

5. Sacada link. Dados culturais pisca-piscando no texto. Uns ostentam Ferrari, outros capitalizam citação. Não a erudição humanista, aquela que estabelece o pacto de educação e civilidade entre texto e leitor, convidado a se deleitar e aprender, mas afetação que delibera se exibir excluindo o outro. Há empilhamento de citações, da epígrafe ao fecho, convertendo poema em varal e autor em wikipoet. Há apropriação lisonjeira, "orgulho da influência", para uma expressão que Paulo Franchetti ${ }^{15}$ parodiou a Harold Bloom, abdicando-se da emulação criativa em prol da emulação servil. Há leitores contentes em achar na cópia o original, no dublê o próprio. É o risco enfrentado em "Vocação do Recife", imitação do antológico "Evocação do Recife", de Manuel Bandeira. Há classicismos jocosos servidos à maneira de palavras cruzadas. E há poetas que, conscientes dessa expectativa, se divertem às custas do

${ }^{15}$ FRANCHETTI, 2001, p. 32. 
leitor que leva o truque a sério. Encena-se uma situação ridícula de leitura, planos sobrepostos. Quem vê apenas o registro grave é vitimado, quem vê o cômico se refestela. Assim em "Possessio diaboli" (mistura de referências latinas, italianas, francesas em tempos históricos misturados) e "Da misericórdia" (na frente Dante, na culatra a mania canina de apartamento).

\section{Vocação do Recife}

Recife sim

das revoluções libertárias

da teimosia ácida

do contra.

Não o Recife da minha infância

de golpe e exílio

gorilas e séquito

de vermes venais.

Recife sim

da coragem Caneca

da conscientização neológica

das lutas ligas lentes

do sempre

não.

Não o Recife sem literatura no papo raso da elite vesga a vida mole e a mente dura. (...)

(Antonio Risério e Frederico Barbosa, Brasilbraseiro, 2004)

\section{possessio diaboli}

Não devo pensar a história

Quintiliano:

Ela deve ser narrada. 
E então o papa declarou que os gatos, assim como outros animais domésticos estavam possuídos

possessio diaboli

os demônios

peludos de Giotto di Bandone.

(vício, espíritos diabólicos)

gatos mortos no fogo

as chamas do inferno na tua cidade

o pelo fede queimado

espalhando a morte

ao que se segue a maior peste que assolou

o Velho Continente.

Je vous salue

Vierge Marie

(Dirceu Villa, Icterofagia, 2008)

\section{Da misericórdia}

non altrimenti fan di state $i$ cani

or col ceffo or col piè, quando son morsi

o da pulci o da mosche o da rafani.

(Inferno, Canto XVII)

Tudo é estopim,

gota de veneno que estraga vários litros d'água

e a surdez do concreto -

um grito

rasga as cordas

vocais. 
Mas o céu é um grande ouvido, cerúleo muro das lamentações,

já na sala

o cachorro, lenta e empenhadamente, coça o cu no tapete.

(Adriano Scandolara, Lira de lixo, 2013)

6. Sacada reflexão. Estilha do gênero didático (docere), propõe nota filosófica, mística ou transcendente. Pensamento que ensina e agrada (delectare) mesmo árduo, daí a reutilização de traços aforísticos, parabólicos e fabulares. Voz poética entre assertiva (movere) e orgulhosa de reparar o que ninguém sacou para além da epiderme cotidiana. Busca-se deslocamento em profundidade, mas quando falta ritmo e tensão semântica, sobra lição do dia, autoajuda de agenda. O perigo é confundir síntese com mini-fatura. Ligeiros, alguns textos parecem carecer de poda ou desenvolvimento. "Pirâmide" articula a dupla face do grande monumento: grande obra de engenharia apontada para a espiritualidade; gigantismo divisível na pedra mínima. Em "Vara o dia", expressões corriqueiras para tempo/cronologia (o sujeito varou o dia) e tempo/clima (o vento varreu a noite) motivam o leitor a achar, ou pelo menos sonhar, o significado/sentido da vida. Por fim, "Enredo"perturba a reflexão amena sobre espiritualidade e existência para mergulhar numa transcendência que supõe queda e dor. É que antes de ser faraó, guru, operário, arqueólogo ou fazer sentido, o homem é mendigo. 


\title{
Pirâmide
}

Para Luciana Whitaker

\author{
Quando \\ retiraram o \\ último bloco de \\ pedra que a prendia \\ ao solo a pirâmide \\ flutuou
}

(Carlito Azevedo, Sublunar, 2001)

$*$

vara o dia

varrendo a noite

cata um sonho

sonha um vento

algo que fique

por pouco

por muito pouco

um cisco que seja

algo que signifique

(Alice Ruiz S., Vice versos, 1988)

\section{Enredo}

Invento minha flor entre dois porcos

e amanheço de óculos numa praça

oca.

Incendeio meus sonhos numa esquina, deixo as cinzas numa encruzilhada sob o choro rasante da amada louca. 
Atravesso o destino com um mendigo
e adoto seu nome
e sua fome.
Com sua voz desdentada eu faço um hino.

Eis o homem.

(Roberval Pereyr, O súbito cenário, 1996)

7. Sacada protesto. Leitor ideologicamente guiado por cena enquadrada como real. Diante da situação social ou política conflituosa, há pouco a escolher no texto, bem e mal estão marcados. Poesia ligada, senão a movimentos, a gestos reivindicatórios, à esquerda ou direita. Alguns poemas manifestam-se como panfleto ou discurso político no modo de persuadir. Os melhores poemas somam à peleja procedimentos que o distinguem do ritmo da assembleia, do palanque. "Para ouvir e entender 'estrela'", trata racismo com virulência e humor, na linha da canção punk "Papai Noel Velho Batuta", dos Garotos Podres. Ouvir estrelas (Estrela é, também, a tradicional fábrica de brinquedos) não significa ser lunático, como no soneto "Ora (direis) ouvir estrelas!"de Bilac, mas acender consciência e ação desde o berço. Em "Perversos XIV", o político é análogo negativo do poeta fingidor pessoano. Ambos têm poder, representam alguém. Mau poeta é inofensivo, descartável. Político vertido em business guy é nefasto à população, que combate injustiça somente com fé. "O barulho dos helicópteros"sobrevoa um mundo dividido entre capitalistas (personificado em bancos) e proletários. Os primeiros são bandidos, os segundos vítimas. Um Roberto Piva que escolhesse trincheira ideológica. Rajadas de imagens geram novos efeitos que não a linearidade da narrativa jornalística e politiqueira sobre as Jornadas de Junho de 2013. Nos três, reduz-se em tipo o 
que seja conservador (racismo, politicagem e burguesia), e amplifica-se a humanidade do oprimido.

\section{Para ouvir e entender "estrela"}

se o papai-noel

não trouxer boneca preta

neste natal

meta-lhe o pé no saco!

(Luiz Silva, o Cuti, Negroesia, 2010)

\section{Perversos XIV}

O político é um fingidor que deveras sente o que está a fingir um prestidigitador

em seu mandato é um semideus.

Políticos, há-os de todos os tipos:

altos, mesquinhos, pequeninos

sobre saltos altos

cheios de dedos ou sem dedos

sinceros em seus arremedos

letrados e analfabetos se emparelham

assinando decretos-lei

promissórias, precatórios

enquanto fazem gargarejo

no espelho.

E nós, aos pés da santa imagem

louvamos ao Senhor

nós degredados filhos de Eva 
filhos da pátria amada

Idolatrada.

(Antonio Miranda, Perversos, 2003)

O barulho dos helicópteros da polícia atrapalha o dendlenzar chatinho do violão $\mathrm{MPB}$

passa pela calçada um homem com o cabelo do Marighela, raspado do lado

ele tem a mesma cara do Marighela

os bancos são quebrados

coitados dos bancos, pobres bancos,

que fazem tanto pelo meio-ambiente, bancos,

bancos que inverteram as coisas e passaram a ser

os coitados que são atacados

bancos que fazem velho chorar, bancos que fazem

um homem colocar o revólver na orelha

e explodir sua cabeça

(no cérebro que voa, os publicitários percebem o

contraste entre as cores

e aproveitam no próximo comercial)

compositores folk, caixas e auxiliares de limpeza, de

mão dadas com os helicópteros

Amarildo desaparecido, estado de exceção

Permanente não é exceção

assassinos eleitos

assassinos contratados por concurso público

descrição das atividades correlatas, cargo amplo,

cada gerente

mas o banco faz mais poesia que esse poema

ele salva o mundo, ele salva Amarildo só para matálo de novo, aos poucos

a PM vai vencer e derrubar os bancos?

ou os bancos vão vencer e endividar os PMs?

há a esquina onde Marighela foi morto e haverá a

esquina onde Amarildo foi morto

garotos e garotas aprendendo história com um 
professor ateu

1984 está na ruas, minha gente

respeitem as faixas amarelas e não escrevam coisas

perigosas demais

os jornais são reescritos e a gente está fudido

(Cássio Corrêa, Sindrome de desfiladeiro, 2013)

8. Sacada visível. À sombra das formulações concretistas, com ou sem rigor. Peças que didatizam a visualidade do verso na página, na quebra da linha, na ideia destacada, no fragmento de palavra. Sacadas mostram-se em andaimes, em construção.Essa sensação de inacabamento, para Marcos Siscar, na modernidade, sugere a própria "manifestação da dificuldade da forma" 16. Mistura de caixa-alta com baixa, tabulação variada, semi-linhas, espaço variável entre sintagmas e estruturas sintagmáticas são como placas de sinalização ao leitor. "Pare nessa palavra". "Devagar no sentido". "Óleo na leitura". "Acidente sintático". "Palavraanimal-valise na pista". No grego e latim antigos, por exemplo, não se grafavam palavras separadamente, o espaço entre elas foi das sinalizações mais bem sucedidas na história da escrita europeia. Difícil violar as regras instaladas pelo poeta aqui, único dono da subversão formal. Em "borboleta-pó", a intervenção gráfica é moderada, restrita ao espaço entre palavras e linhas, sinalizando onde contrastar os trinômios voo/liberdade/poesia vs. estática/ prisão/comunicação. Para um empréstimo à semiótica greimasiana, devemos sobrepor disforia e euforia, poesia como prisão premiada, atualização do malsinado poeta romântico. Leminski, massificador de tantas modalidades de sacada, insere no subtítulo de seu volume mais vendido (Caprichos e Relaxos) justamente o termo "saques". No poema abaixo, a poesia

${ }^{16}$ SISCAR, 2010, p.115. 
é foco e explode apesar do sólido/enorme (ditadura) e do perene/pequeno (cotidiano). Ela é força da natureza mais que do raciocínio, arrebentada pré-criação, do escuro e de todos os sons em " $u$ " (soturnos, elegíacos) para se corporificar no som aberto de "ode". No seguinte, há um móbile de palavras picotadas a dizer o óbvio demais para um alexandrino, caso lêssemos todos os sintagmas juntos: a vida é por um fio.

\section{borboleta-pó de khliébnkov}

só borboleta em voo cego

na cela do viver apenas lego

as letras do meu pó no vidro austero

para a assinatura do prisioneiro

nas janelas severas do destino

(Augusto de Campos, Despoesia, 1994)

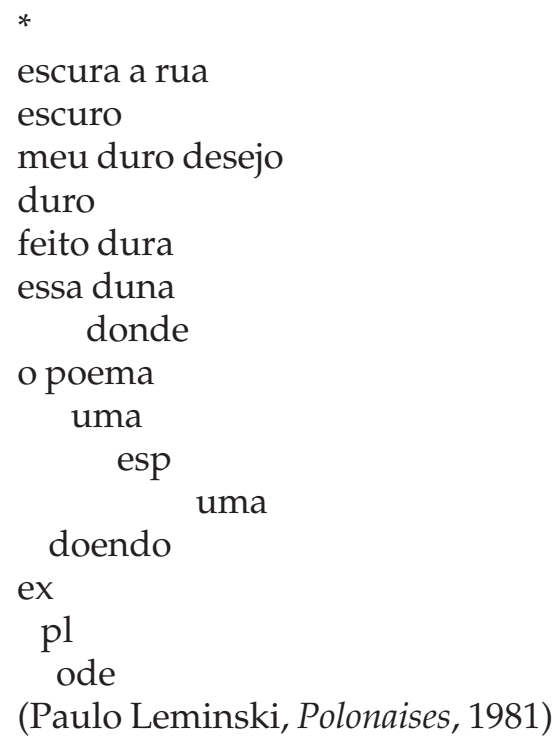




$*$
a vida:
fino
desa
fio
con
$\quad$ tra
a
mor
te

(Roosevelt Rocha, Primícias, 2002)

9. Sacada randômica. Ritmo no compasso de imagens, para recordar o"Verso e prosa," de Octávio Paz. Sacadas amarradas em mosaico disforme, rejuntando escombros de imagem, de discurso, espécie de cubismo às avessas, isto é, o referencial já está em pedaços. São, talvez, os poetas menos catalogados por editoras pequenas ou parrudas. Montam sequências alucinógenas, memória sem roteiro. Criam certa expectativa realista, mas entregam a nitidez apenas do caco isolado. Usam métrica, polimetria ou verso livre, mas as imagens brigam com a rítmica (rima, pé, estribilho, compasso de tempo etc.) numa edição randômica, num tumulto sinestésico. A irresolução entre corte surrealista e cenário organizado faz o poema falar sem assunto, micro unidades de soma estranha. Take claro, montagem obscura.Em lugar de áudio-descrição para cegos, vídeo-distorção para lúcidos. Em "Cheiros Cerzidos", informações tácteis, olfativas e visuais desenham acordes sensoriais, frisados por fusões de palavras (meus olhos, entrededos), drinks a Des Esseintes. "Os fantasmas" embaralham bruxa, eu lírico, praça ou mulher nesse carnaval de horror. E o que são fantasmas senão espectros e visões indefinidas? Por fim, "o choro do palhaço II" arruma sonoridade cômica, como se ela fosse roupa e 
maquiagem do palhaço-poema. Tudo descompasso, melodia de tango em ritmo de rock, adereços humanos invisíveis, doloridos, só materializados na capotagem. Sob a fantasia, a tragédia dói o trocadilho com Florbela Espanca. O choro do palhaço é a única verdade da cena.

\section{Cheiros cerzidos}

É quando sinto seu cheiro

Que meus olhos cerzem reticências:

Quando o mundo se refaz,

Em meio às aparências.

Trago constelações de sonhos entrededos,

Quatro manhãs, três primaveras

Pra romper silêncios, cingir quimeras

Deixando em potes os nossos segredos.

Mas o que mais guardo em mim

São palavras que não atingem o fim.

Silêncios do seu cheiro nos meus sentidos,

Meus sonhos serenando nos seus vestidos.

(Ricardo Flaitt, O domesticador de silêncios, 2013)

\section{Os fantasmas}

A nua na rua

A praça espia

Estremeço - os faróis avisam:

Ela insinua

Os pés descalços feridos

Alcançam a praça

Os olhos fincados na cara - crateras

Formas e veios 
Por onde escoam

O sangue e as preces

É bruxa é gente é falsa?

A nua espalha

Terror e desgraça

Quieta a praça aborta filhos inválidos

A lua me chama de volta

Os fantasmas se fazem de mortos

(Cida Sepulveda, Sangue de romã, 2004)

\section{o choro do palhaço II}

Não posso mais morgar nesse mormaço, não sei se morro logo ou se me arranco; quero explodir de rir com estardalhaço, quero matar ou assaltar um banco.

Se um dia me foder inda me manco, mereço cometer um erro crasso: broxar pra todo o sempre, ficar manco, perder uma mulher, quem sabe um braço...

O que pintar na minha estrada eu traço, se o carro der o prego, vai no tranco e eu me aguento a cada solavanco dos atravancos de por onde passo.

Não sei se negligente ou se devasso, vou meter esse carro num barranco; o risco que eu corro eu mesmo banco e a flor da juventude pede amasso.

Vou mal do fígado e talvez do baço, quero desopilar o que retranco; 
não sou Florbela, mas também espanco

e, agora, canto o choro do palhaço!

(João Miguel Moreira Auto, Mausoléu, 2009)

\section{III}

Analisar e interpretar a poética da sacada modalizando critérios teórico-historiográficos do século XX, ou seja, não arrebentar poemas de hoje com limas e alicates de ontem. Requer ainda mais cuidado a instabilidade, fragilidade e novidade do objeto. Driblar o sistema Carlitos. O vagabundo fecha as roupas numa mala e fica algum tecido de fora. Objetivo, ele tesoura os nacos de mangas e punhos sobressalentes. Método resolvido, poema destruído, como fez a crítica romântico-nacionalista com a poesia colonial. A conclusão, aqui, não podia ser unívoca frente à fauna de poetas e sacadas. Os poucos textos mencionados me conduziram a ver o problema de três modos que, a depender, se excluíam ou se somavam.

A poética da sacada, como língua geral e sem controle, não marca nosso tempo. Incapaz de alterar a percepção comum pela poesia, despretensiosa e sem projeto, seria a prática da ordem, semiconsciente, integrada demais ao contexto. É que, em arte, importa a atualidade processada, sujeita à intervenção e à refundação do gênio humano. Ora, espalhadas e desregradas, as sacadas, no máximo, se conformam à demanda, não a deformam nem a idealizam. É o modo normativo de olhar a questão, buscando controlar a criação numa gramática outorgada, isto é, baseada em fenômenos mas definidora do certo e do errado. Por essa via parece caminhar Giorgio Agamben, ${ }^{17}$ quando legisla o que seja contemporâneo, feito historiador da literatura que sintetiza

${ }^{17}$ AGAMBEN, 2009, p. 58-72. 
o espírito ou estética de uma época. Apoiado no Nietzsche das "Considerações intempestivas", num texto de sabor literário, fixa que é verdadeiramente contemporâneo quem não coincide plenamente com seu tempo. $\mathrm{O}$ poeta deve aderir a seu tempo "através de uma dissociação e um anacronismo", só assim apreenderia não apenas o claro e as continuidades, mas, sobretudo, o escuro e as fraturas. Difere-se o atual do contemporâneo. Um poeta de sacada, nessa perspectiva, não passaria de atual.

A poética da sacada é sintoma da famigerada crise contemporânea.Assim como o poeta nada mais significa no coro político-social, as sacadas já não inovam o discurso relevante. Em solo brasileiro, o poeta compôs o corpo místico, participou do estado político, co-inventou o estado nacional e, por fim, brilhou na república das letras. Sua obra e sua posição de artífice moveram os passos do gigante, até que outras experiências simbólicas e práticas reduziram poesia a bibelô, a animal de estimação, a relíquia em sala de família, a hino a ser ensinado por força de lei. É o modo trágico de olhar a questão, a especialização da poesia colapsou-a a ponto de furar seus próprios olhos. Daí vozes como a de Alcir Pécora sugerirem que, hoje, teóricos (da cultura, da política ou da literatura) ressoam socialmente mais e são linguisticamente mais inventivos que romancistas e poetas. Em suas palavras, "fico imaginando se essa não será uma forma de literatura disfarçada. Uma nova máscara da literatura". ${ }^{18}$

A poética da sacada, finalmente, comanda as ações, é o prato do dia. Se a modernidade destruiu certezas (de método, de crença e de arte), a contemporaneidade desapareceu com incertezas. Havia pelo menos a terra devastada para reconstruir, agora não amamos mais a terra nem temos motivos para reconstruí-la. É tempo em que ilusões de totalidade e de corpo poético desvalem. Vive-se os pedaços que cada um junta para

18 PÉCORA, 2011. 
sonhar seu todo, que por sua vez já nasce cercado pela próxima moda, vírus ou demolição. É o modo reboot de olhar a questão, catar sacadas para montar o poema particular num eu leitor, consumidor de tudo e de si, abstraído de eu líricos bestiais ou geniais. João Adolfo Hansen ${ }^{19}$ destaca o "liquidificador que é o mundo contemporâneo", essa "des-hierarquização do valor" que triturou de vez os conceitos literários com que buscamos nos comunicar sobre um poema. Ler ou ver sacadas, assim, é exercício de reconstituir sentidos, identidades e valores que um dia acreditamos estáveis, de criar poemas mentais sobre poemas uma noite concluídos. Leitor é quem reinicia sua obra alheia a cada poema refeito de sacadas.

\section{Referências bibliográficas}

AGAMBEN, Giorgio. O que é contemporâneo e outros ensaios. Tradução Vinícius Nicastro Honeko. Chapecó, SC: Argos, 2009.

ANDRADE, Mário de. Pauliceia desvairada [1922]. Poesias completas. São Paulo: Círculo do Livro/Martins, 1983.

ANDRADE, Oswald. de. Pau-brasil [1925]. Cadernos de Poesia do aluno Oswald (Poesias reunidas). Organização: Haroldo de Campos. São Paulo: Círculo do Livro/Civilização Brasileira, 1981.

ARISTÓTELES. "Poética". In: Os Pensadores - Aristóteles. Tradução e notas Eudoro de Souza. São Paulo: Abril Cultural, 1973.

. Poética. Edição trilíngue por Valentín García Yebra.Madri: Editorial Gredos, 1974.

AUTO, João Miguel Moreira. Mausoléu. São Paulo: Editacuja, 2009.

${ }^{19}$ HANSEN, 2013. 
AZEVEDO, Carlito. Sublunar. Rio de Janeiro: 7Letras, 2001.

BARROS, Manoel de. Concerto a céu aberto para solos de ave [1991]. Rio de Janeiro/São Paulo, Record, 2008.

BESO. Juventude supersônica. Campinas, SP: Do Autor, 2008.

BONVICINO, Régis. Estado crítico. São Paulo: Hedra, 2013.

CALIXTO, Fabiano. Sanguínea: 2005-2007. São Paulo: 34, 2007.

CAMÕES, Luís de. Versos e alguma prosa. Prefácio e seleção Eugênio de Andrade. Lisboa: Fundação Calouste Gulbenkian/Moraes, 1977.

CAMPOS, Augusto de. Despoesia: 1979-1993. São Paulo: Perspectiva, 1994.

CARMACHO, Caio, Livre-me. São Paulo: Patuá, 2013.

CHACAL, Ricardo. “Letra elétrika" [1994]. In: Belvedere: 1971-2007. São Paulo/Rio de Janeiro: Cosac Naify/7Letras, 2007.

CORRÊA, Cássio. Síndrome de desfiladeiro. Campinas, SP: Do Autor, 2013.

FERREIRA, Antonio Geraldo Figueiredo. Peixe e míngua. São Paulo: Nankin, 2003.

FLAITT, Ricardo. O domesticador de silêncios. São Paulo: Centro de Memória Sindical, 2013.

FRANCHETTI, Paulo. "Entrevista a Ademir Demarchi". In: Babel - revista de poesia, tradução e crítica. Santos, SP/Florianópolis / Campinas, SP: Ano II, No. 4, janeiro a dezembro de 2001

FREITAS, Angélica. Um útero é do tamanho de um punho. São Paulo: Cosac Naify, 2012.

GRACIÁN, Baltasar. Agudeza y Arte de Ingenio, Tomo I. Edición, introducción y notas de Evaristo Correa Calderón. Madrid: Clásicos Castalia, 1987.

HANSEN, João Adolfo. "Entrevista a Edson Cruz". In: Musa Rara. São Paulo: 24/11/2013. 
JAKOBSON, Roman. "Dois aspectos da linguagem e dois tipos de afasia". In:Linguística e Comunicação.Tradução Izidoro Blikstein e José Paulo Paes. São Paulo: Cultrix, 1992.

JÚNIOR, Carvalho. Parisina (Teatro, Versos, Folhetins, Crítica Literária e Escritos Políticos). Rio de Janeiro: Tipografia de Agostinho Gonçalves Guimarães e Cia., 1879.

LEMINSKI, Paulo. "Polonaises" [1981]. In: Caprichos e relaxos. São Paulo: Brasiliense/Círculo do Livro, 1987.

NEUSTEIN, Ana. Poemas. São Paulo: Editora da Autora, 2012.

MELLO, Heitor Ferraz. "A mesma noite" [1997]. In: Coisas imediatas: 1996-2004. Rio de Janeiro: 7Letras, 2004.

MIRANDA, Antonio. Perversos. Brasília: Thesaurus, 2003.

OLIVEIRA, Manuel Botelho de. Música do Parnaso. Lira sacra. Introdução e organização Adma Muhana. São Paulo: Martins Fontes, 2005.

PAIXÃO, Fernando. Poeira. São Paulo: 34, 2001.

PAZ, Octavio. "Verso e prosa". In: Signos em rotação. Tradução Sebastião Uchoa Leite. São Paulo: Perspectiva, 2003.

PÉCORA, Alcir. "Impasses da literatura contemporânea". In: Prosa E Verso. Rio de Janeiro: O Globo, 23-04-2011.

PEDROSA, Celia. “Poesia contemporânea: crise, mediania e transitividade (uma poética do comum)". In: Subjetividades em devir: estudos de poesia moderna e contemporânea. Rio de Janeiro: 7Letras, 2008.

PEREYR, Roberval. O súbito cenário. Feira de Santana, BA: Edições Cordel, 1996.

RICOEUR, Paul. "Estudo I - Entre retórica e poética: Aristóteles". In: A metáfora viva. Tradução Dion Davi Macedo. São Paulo: Edições Loyola, 2000.

RISÉRIO, Antonio; BARBOSA, Frederico. Brasilbraseiro.São Paulo: Landy, 2004.

ROCHA, Roosevelt. Primícias. Goiânia: Do Autor, 2002. 
ROQUETTE-PINTO, Claudia. Corola. Cotia, SP: Ateliê, 2000.

RUIZ S., Alice. "Vice versos" [1988]. In: Dois em um. São Paulo: Iluminuras, 2008.

SCANDOLARA, Adriano. Lira de lixo. São Paulo: Patuá, 2013.

SEPULVEDA, Cida. Sangue de romã. São Paulo: Scortecci, 2004.

SILVA, Luiz (Cuti). Negroesia. Belo Horizonte: Mazza, 2010.

SISCAR, Marcos. "Poetas à beira de uma crise de versos". In: Poesia e crise. Campinas, SP: Editora da UNICAMP, 2010.

VILLA, Dirceu. Icterofagia. São Paulo: Hedra, 2008.

\section{Resumo}

A poética da sacada é das linhagens decisivas da poesia brasileira em décadas. Até quem evita, não raro propõe saídas a ela. Como achado de pensamento ou de linguagem, a sacada deriva da alteração provocada por toda figura retórica na língua corrente. Como operação radical com valor em si conecta-se a rupturas perpetradas por vanguardas, no caso, modernistas e concretistas. Pela quantidade e variedade de publicações, de tons humorísticos aos filosóficos, trata-se da vertente dominante, cujos usos, rigorosos ou facilitadores, privilegiam a sacada como unidade ante-poema, antelivro. Procuro, assim, distinguir o procedimento, enquanto engrenagem de uma máquina de técnicas e sentidos, do mero truque, isto é, "uma ideia na cabeça, um teclado nas mãos".

\section{Abstract}

The poetic insight is one of the strong features of Brazilian poetry in decades. Even those poets who are not of this lineage, sometimes propose alternatives to it. An insight, as invention of thought or language, arises from any 
rhetorical figure that causes some change in current language.As a radical action, with value itself, it connects to breaks conducted by the vanguards, in the Brazilian case, modernists and concretists.In quantity and variety of publications, from the funnier to the more philosophical, the poetic insightis the dominant line, their rigorous or facilitators practices prefer the insight as an unit-poetic in place of the poem or book. So here, I try to distinguish the procedure, as cogs in a techniques machine and meanings, from de simple trick, in fact, "idea in mind, keyboard in hands". 